This PDF is a selection from a published volume from the National Bureau of Economic Research

Volume Title: Organizations, Civil Society, and the Roots of Development

Volume Author/Editor: Naomi R. Lamoreaux and John Joseph Wallis, editors

Volume Publisher: University of Chicago Press

Volume ISBNs: 978-0-226-42636-5 (cloth); 0-226-42636-X (cloth)

Volume URL: http://www.nber.org/books/lamo14-1

Conference Date: October 24-25, 2014

Publication Date: November 2017

Chapter Title: Corporation Law and the Shift toward Open Access in the Antebellum United States

Chapter Author(s): Eric Hilt

Chapter URL: http://www.nber.org/chapters/c13508

Chapter pages in book: (p. $147-177)$ 


\title{
Corporation Law and the Shift toward Open Access in the Antebellum United States
}

\author{
Eric Hilt
}

\subsection{Introduction}

Over the course of the nineteenth century, business corporations became increasingly common elements of the American economy, and their proliferation transformed economic life. Among the most important legal innovations that facilitated this expansion in the use of the corporate form was the enactment of general incorporation statutes by the states. Prior to the adoption of a general statute, a business could only incorporate if the state passed a special law granting it a corporate charter. ${ }^{1}$ This regime of special charters created problems, both practical and political: petitioning the legislature could be slow or prohibitively costly for some entrepreneurs, and legislative discretion over access to incorporation led to serious problems of corruption. $^{2}$ Many states responded to these problems by enacting general incorporation statutes, which created a simple administrative procedure by which firms could incorporate. Under the terms of these statutes, entrepreneurs simply filed a certificate with information about their firm with a government office, and when their certificate was recorded their firm was

Eric Hilt is associate professor of economics at Wellesley College and a research associate of the National Bureau of Economic Research.

I would like to thank Naomi Lamoreaux, Tim Guinnane, Richard Brooks, and John Wallis, along with participants at the NBER Civil Society conference held at Yale University, for helpful comments. For acknowledgments, sources of research support, and disclosure of the author's or authors' material financial relationships, if any, please see http://www.nber.org /chapters/c13508.ack.

1. The historical origins of the doctrine that incorporation was possible only through a special law are explored in Hurst (1970). At the time, legal barriers made it necessary for corporations to be incorporated in the state in which they operated. See the discussion below.

2. On the corruption associated with special chartering, see Wallis (2006). 
incorporated. Incorporation became a routine, inexpensive matter outside the realm of political influence.

General incorporation statutes thus democratized access to an important organizational technology. They have been highlighted as momentous reforms that created open-access orders (North, Wallis, and Weingast 2009), changed the legal conception of the corporation to one that is fundamentally private in nature (Horwitz 1977), and weakened the role of the state in regulating corporations (Berle and Means 1933). Yet owing to the difficulty of identifying and analyzing the different states' and territories' early general statutes, little systematic information has been collected about them, and there is considerable uncertainly in the literature about the contents, or even the dates, of most states' early general acts. Most of the scholarship on these statutes resorts to making broad generalizations on the basis of relatively little evidence. ${ }^{3}$ Given the importance that is generally ascribed to these statutes, this lack of systematic analysis is surprising. It is not possible to assess the impact or significance of the transition to general incorporation without first understanding when and where it occurred, and the content of the laws that were actually enacted.

This chapter analyzes the general incorporation statutes for manufacturing enterprises enacted by the American states in the years up to 1860. It presents new, comprehensive data on the adoption of general statutes and on the content of those statutes. These data are then used to analyze the political and economic forces that shaped the decision to adopt a general act, and to document the variation in the substance of general acts across regions and over time. A number of hypotheses related to assertions made in the literature about early general statutes are then investigated.

The analysis proceeds in three steps. First, I present a new chronology of the earliest general incorporation acts for manufacturing firms of each state or territory prior to 1860 , obtained from a careful search of state session laws, legal codes, and statute revisions. The resulting list improves upon the widely used tabulations of Hamill (1999), and in particular includes eight general incorporation acts omitted from that list. The new chronology indicates that a number of states enacted general laws for manufacturing corporations several decades earlier than had been previously reported.

In the second step, I use the new list of general acts to analyze the political and economic determinants of states' transitions to general incorporation. Using newly available data on the total number of special charters for business corporations in each state from Sylla and Wright (2013), and census data on the social and economic structure of the states and territories, I estimate a simple linear probability model of the decision to adopt a general

3. The most prominent example is Berle and Means (1933, 126-27), who argue on the basis of a wholly incomplete chronology of general acts. An important exception is Hamill (1999), who presents a chronology of the dates of adoption of these statutes. 
act prior to 1860 . The results indicate that states with higher proportions of their population engaged in agriculture or commerce were less likely to adopt a general act, which may be a reflection of interest-group politics, if those sectors were opposed to the proliferation of limited liability corporations. The results also indicate that smaller states were less likely to adopt a general act. In a small state, the costs of petitioning the state government for a charter may have been lower, and the willingness of a state government to accommodate such petitions may have been higher - both of which would have reduced the benefits of adopting a general act. Evidence consistent with this latter point is found in the data on special-act charters, which indicate that the states that did not adopt general statutes typically offered extraordinarily liberal access to special charters. This suggests that broad access to the corporate form was sometimes achieved without general statutes, and that the enactment of a general statute may not always have created a substantial, discrete increase in the accessibility of incorporation.

Early general acts did not grant entrepreneurs the freedom to configure their enterprises however they wished, but instead created an organizational template that corporations were required to adopt. This template sometimes imposed strict conditions on the size, industry, operations, capital structure, and internal governance of the corporations created. But the rigidity and restrictiveness of the organizational template varied considerably across states. In the third step, I present a detailed analysis of the terms of the states' general incorporation acts as amended in 1860 . The statutes often contained detailed provisions intended to protect the interests of creditors, such as limits on indebtedness, regulations of capital contributions, disclosure requirements regarding paid-in capital, and punitive measures that stripped directors or stockholders of their limited liability in response to actions that imperiled the firms' capital. Many of the other regulations written into the statutes were intended to give the state leverage over the firms, for example, by limiting the duration of their incorporation.

The analysis of the terms of the statutes also reveals that there was considerable variation in the degree of their restrictiveness across states. Southern states' general laws in particular tended to be more permissive than those of other states. On the other hand, Southern states frequently imposed rules that either explicitly forbade certain segments of society from making use of their general statutes, or granted discretion over the use of the law to a government official, who could choose to exclude anyone from using the law for any reason. The early general laws of Southern states were thus at once more permissive and more restrictive than those of other states, and perhaps can only be termed "general" laws in a qualified sense. General statutes did not always create truly open access to the corporate form.

The data and analysis presented in this chapter contribute to a large and prominent literature on the evolution of American corporation law over the nineteenth century, and the resulting changes in the relationship between the 
state and the corporation. A number of works in this literature have focused on the role of general statutes in this evolution, with some arguing that they circumscribed the state's role in constituting or regulating corporations (e.g., Berle and Means 1933; Horwitz 1977), whereas others have emphasized the strict regulations imposed in many early general acts (Millon 1990; Hurst 1970). What is missing from this literature is a systematic analysis of the terms of these statutes - the regulations they imposed, and the matters they left unregulated. These statutes also created some of the earliest regulations of dividend payouts, financial reporting, director elections, capital contributions, and the rights of creditors. The analysis of this chapter therefore complements the literatures on the historical origins of such regulations in the United States.

A smaller literature has analyzed the history of general statutes in particular states (e.g., Seligman 1976), the rates at which the statutes of individual states were utilized (e.g., Kessler 1940; Bodenhorn 2008), and the forces influencing states' decisions to implement general statutes (Butler 1985). This chapter complements those earlier works by presenting comprehensive data that can be used to understand the extent to which individual states' experiences are representative, and to evaluate hypotheses regarding the determinants of the adoption of general laws.

This chapter also contributes to the literature on the suitability of the corporate form in general, and American corporation laws in particular, for the needs of small- and medium-sized enterprises (SMEs). Recent contributions to this literature have argued that the corporate form was inflexible in important respects, and the alternative forms that became available in the twentieth century, such as the limited liability company (LLC), were superior for the needs of SMEs (Guinnane et al. 2007). This chapter contributes to that literature by providing detailed documentation of the ways in which the states' corporation laws were restrictive or permissive.

\subsection{Early General Acts: Their Adoption and Their Terms}

In order to collect a comprehensive list of early general incorporation statutes, a careful search of each state's session laws, legal codes, and statute revisions up to 1860 was undertaken. ${ }^{4}$ The results of this search are presented in table 5.1, which lists the date of each state or territory's first general incorporation statute - or in cases where a statute was repealed, the date of their second statute-along with the citation of the statute

4. The names by which these statutes refer to the corporations they create vary widely, and include "joint stock companies," "corporations," "companies," "associations," and even "private associations and partnerships," which makes identifying these acts within a state's laws difficult. The names given in previously documented general statutes were used to create search terms, and as new statutes were identified, any new terms that arose were used to conduct further searches. 


\begin{tabular}{|c|c|c|}
\hline Year & State & Citation; major amendments or additional legislation up to 1860 \\
\hline 1811 & New York & $\begin{array}{l}\text { Laws, Ch. } 67 \text {; Laws, } 1848 \text {, Ch. } 40,1853 \text {, Ch. } 333 \text {, 1855, Ch. } 301 \text {, } \\
\quad \text { 1857, Ch. } 29 \text {, Ch. } 262\end{array}$ \\
\hline 1812 & Ohio* (repealed 1824) & Laws, Ch. 15 \\
\hline 1816 & $\begin{array}{l}\text { New Jersey* (repealed } \\
\text { 1819) }\end{array}$ & Laws, Feb 9, 1816 \\
\hline 1824 & Illinois* (repealed 1833) & Laws, December 16, 1824 \\
\hline 1836 & Pennsylvania & $\begin{array}{l}\text { Laws, No. 194; Laws, } 1849 \text {, No. } 368 \text {, } 1851 \text {, No. } 295 \text {, } 1852 \text {, No. } \\
\quad 371,1853 \text {, No. } 186,1860 \text {, No. } 341\end{array}$ \\
\hline 1837 & Connecticut & Laws, Ch. 63; Revised Statutes (1854), Title III \\
\hline 1837 & Michigan* & Laws, No. 121; Laws, 1853, No. 41, 1855, No. 19, 1857, No. 76 \\
\hline 1846 & $\begin{array}{l}\text { Ohio (first after repeal of } \\
1812 \text { act) }\end{array}$ & $\begin{array}{l}\text { Laws, Feb. 9, 1846; Laws, May 1, 1852, April 17, 1854, May 1, } \\
\text { 1854, March 30, 1857, April 12, } 1858\end{array}$ \\
\hline 1846 & $\begin{array}{l}\text { New Jersey (first after } \\
\text { repeal of } 1816 \text { act) }\end{array}$ & $\begin{array}{l}\text { Laws, Feb. 25, 1846; Laws, March 2, 1849, March 7, 1850, } \\
\text { February 25, 1852, March 10, 1853, March 15, 1860, March 22, } \\
1860\end{array}$ \\
\hline 1847 & Georgia* & Laws, December 22, 1847 \\
\hline 1847 & Iowa & Laws, Ch. 81; Revised Statutes (1860), Title X \\
\hline 1848 & Louisiana & Laws, No. 100; Revised Statutes (1856) \\
\hline 1849 & Wisconsin & Laws, Ch. 51; Revised Statutes (1858), Ch. 73 \\
\hline 1849 & $\begin{array}{l}\text { Illinois* (first after repeal } \\
\text { of } 1824 \text { act) }\end{array}$ & Laws, Feb. 10, 1849; Laws, February 18, 1857, April 26, 1859 \\
\hline 1849 & Missouri* & $\begin{array}{l}\text { Laws, March 12, 1849; Revised Statutes (1855), Ch. 37, Laws, } \\
\quad \text { 1855, Ch. } 34\end{array}$ \\
\hline 1850 & California & $\begin{array}{l}\text { Laws, Ch. 128; Compiled Laws of California (1853), Ch. 77, Ch. } \\
\quad 78 \text {, Laws, 1858, Ch. } 181\end{array}$ \\
\hline 1850 & Tennessee & Laws, Ch. 179; Code of Tennessee (1858), Title 9, Ch. 2 \\
\hline 1851 & Arkansas* & Laws, Jan 2, 1851 \\
\hline 1851 & Vermont & Laws, No. 60; Compiled Statutes (1851), Ch. 83 \\
\hline 1851 & Massachusetts & Laws, Ch. 133; General Statutes (1859), Chs. 60 and 61 \\
\hline 1852 & Alabama & Code of Alabama, Part 2, Title 2, Ch. 3 \\
\hline 1852 & Florida & Laws, Ch. 490 \\
\hline 1852 & Indiana & Revised Statutes, Ch. 66 \\
\hline 1852 & Maryland & Laws, Ch. 322; Maryland Code (1860), Art 26 \\
\hline 1852 & North Carolina & Laws, Ch. 81; Revised Code (1854), Ch. 26, Laws, 1855, Ch. 31 \\
\hline 1854 & Kentucky & Laws, Ch. 1012 \\
\hline 1854 & Virginia & Laws, Ch. 47; Code of Virginia (1860), Ch. 57 \\
\hline 1857 & Mississippi & Revised Code, Ch. 35 \\
\hline 1858 & Minnesota & Laws, Ch. 78 \\
\hline 1859 & Kansas Territory & Laws, Ch. 490; Revised Statutes (1855), Ch. 28 \\
\hline
\end{tabular}

*Denotes statutes not included in the Hamill (1999) tabulation. 
itself and any important amendments or supplemental legislation. General statutes not included in the Hamill (1999) tabulation are identified with an asterisk.

The list presented in the table suggests that the transition to general incorporation began with halting experimentation. In the first four decades of the nineteenth century, just seven states enacted general laws, and three ultimately repealed them and reverted to regimes of special incorporation. Beginning in the mid-1840s, however, growing numbers of states began to enact - and retain — general statutes, and by 1860 the vast majority of the states and organized territories had one in place.

The adoptions of general statutes began in two small waves, the first occurring in 1811-24 and the second in 1836-37. The first wave commenced around the time of the War of 1812, and the statutes enacted during that period were likely intended to encourage the development of domestic manufacturing. Trade restrictions enacted prior to the war, such as the Embargo Act of 1807, blocked American access to imports and created opportunities for domestic firms to replace foreign sources of manufactured goods. ${ }^{5}$ In the years 1808-1811, incorporations of manufacturing firms via special-act charters rose significantly, reflecting a substantial increase in demand for charters, as well as an apparent willingness of state governments to accommodate that demand. ${ }^{6}$ Finally, in 1811 the State of New York took the radical step of enacting a general incorporation statute for manufacturing firms. ${ }^{7}$ Laws similar to New York's were passed in Ohio in 1812, in New Jersey in 1816, and in Illinois in $1824 .{ }^{8}$

New York's 1811 act imposed a relatively rigid template on the firms it created, but the template itself was quite similar to the terms of specialact charters of manufacturing companies granted by the state during the preceding years. Some elements of the law were also likely influenced by the state's 1784 general incorporation act for religious congregations. The statute precisely enumerated the industries in which the firms could operate; limited the size of the board of directors to nine persons, who were required to be stockholders; limited the capital stock to a maximum of $\$ 100,000$ and limited the duration of the firms' existence to twenty years; and required that each stockholder be granted "as many votes as he owns share of the stock"

5. The effects of these disruptions on domestic manufacturing are assessed in Irwin and Davis (2003).

6. For example, in 1909 and 1910, the state of New York granted charters to twenty-five manufacturing corporations; for all years prior to 1909 , the state had only chartered three (Laws of New York 1784-1810).

7. In the discussion that follows, citations of individual states' statutes are omitted, as they are provided in table 5.1.

8. These laws are not noted in much of the previous scholarship on general incorporation statutes (e.g., Hamill 1999). No comprehensive data on their use seems to survive. McCormick and McCormick (1998) include a detailed description of one firm that incorporated through Ohio's first general act. 
of the company in director elections. ${ }^{9}$ Other parts of the act empowered the directors to write the firms' bylaws, limited the liability of the stockholders to "the extent of their respective shares in the company, and no further," and enumerated the powers of the corporations created. ${ }^{10}$ The statute also made company stock personal estate, and transferable "in such manner as shall be prescribed by the laws of the company." Finally, it required that all directors be residents of the state in its stipulation that their "removal out of the state" would create a vacancy on the board.

The statutes of Ohio, New Jersey, and Illinois all followed the structure and language of New York's 1811 statute, but modified particular terms. For example, the statutes of New Jersey and Illinois followed New York in imposing a rule of one vote per share, whereas Ohio mandated a graduated voting-rights scheme in which the number of votes per share each shareholder was entitled to was a decreasing function of the number of shares held. ${ }^{11}$ And whereas Ohio and New Jersey followed New York in granting shareholders limited liability (with New Jersey imposing the rule that stockholders were responsible for the amount of their shares plus all the accumulated dividends they received), the statute of Illinois made shareholders personally liable for their firms' debts. But with the exception of New York's, these acts were all repealed: New Jersey's in 1819, Ohio's in 1824, and that of Illinois in 1833 - at which point New York was once again the only state or territory with a general statute for manufacturing enterprises.

A second brief wave of adoption of general statutes began in 1836, when Pennsylvania enacted a general incorporation law for iron manufacturers. Pennsylvania's law was similar in some respects to those that preceded it, but it applied only to firms in a narrowly defined industry, and required a minimum of $\$ 100,000$ in capital. ${ }^{12}$ Pennsylvania's law is noteworthy because it introduced the innovation of requiring the attorney general and the governor to scrutinize all certificates of incorporation, and empowered the governor to withhold approval of incorporations if there were any doubt regarding the "lawfulness" of the proposed enterprise or the amount of

9. Following the state's general act for religious congregations, the statute refers to the directors as "trustees." The general act for religious congregations required those organizations to have boards of trustees of three to nine persons as well (Laws of New York 1784, ch. 18).

10. This language with respect to shareholder liability was interpreted by the courts to mean what would be termed today "double liability" (see Howard 1938). Most of the subsequent statutes that granted limited liability to shareholders did so with similar language.

11. Ohio's statute stated that "each stockholder shall be entitled to one vote for each share he may own below ten; for all above ten and not exceeding twenty, one vote for every two shares; and for every five shares above twenty, one vote." On graduated voting rights, see Hilt (2008; 2013).

12. Pennsylvania's law applied only to firms "manufacturing iron from the raw material, with coke or mineral coal" and specifically excluded firms producing iron "which has not been manufactured from the ore, with coke or mineral coal." Pennsylvania's 1836 act was also unusual in that it imposed graduated voting rights, and included several special charters for specific corporations, including a coal company and turnpike road company. 
the capital stock "actually paid in." In contrast, in the other states' laws, incorporation was automatic once a certificate was filed. Although the language of Pennsylvania's statute could be interpreted as merely enforcing compliance with its terms, the discretion granted to the government officials scrutinizing certificates may have been broad enough to enable them to reject proposed incorporations for other reasons. ${ }^{13}$

In 1837 Michigan, having just become a state, enacted a general incorporation law quite similar to those of the 1811-24 period, but like Illinois it imposed unlimited liability for all shareholders. ${ }^{14}$ Also in 1837 , Connecticut passed a general incorporation act that was the first to not specifically enumerate the industries that could be pursued, or to limit the duration of the existence of the corporations it created. The Pennsylvania and Connecticut laws from this period were also the first to require corporations to make an annual report to the state.

No subsequent general acts were passed until the second half of the 1840s. The beginning of this third period of activity in enacting general laws coincides with episodes of fiscal distress among many American states, some of which responded with significant constitutional reforms, particularly regarding provisions relating to corporations (Wallis 2005). ${ }^{15}$ The first states to enact general laws in this period were Ohio and New Jersey, which passed new laws in 1846. Georgia and Iowa followed in 1847, Louisiana in 1848 , and in 1849, Wisconsin and Missouri enacted general laws for the first time, while Illinois enacted its first since the repeal of its 1824 law. Whereas most of these statutes were similar to those of earlier decades, Iowa's 1847 law was radically innovative. It imposed no restrictions whatsoever on the internal governance of the firms it created, and in fact did not even mention directors or a procedure for voting or decision making. It simply said that any number of persons - even just one - may incorporate a firm, make its shares transferable, and "exempt [their] private property from corporate debts." With regard to governance institutions and procedures, it stated that the incorporators "may make such regulations as they please in relation to the management of their business." Iowa's statute also did not impose any restrictions on the size of the capital stock, although it did limit the duration of the corporations' existence to twenty years.

In contrast, Iowa's neighbor to the northeast, Wisconsin, adopted a statute that was as restrictive as Iowa's was permissive. Wisconsin's statute not only regulated the structure and governance of corporations, but it imposed unlimited liability on stockholders and also required them to employ a rule

13. Pennsylvania substantially revised its law in 1849 , making it applicable to firms in a broad range of industries, and removing the provision granting the governor authority over access to the act.

14. Michigan substantially revised its law in 1846 , with new terms that granted shareholders limited liability.

15. As Wallis notes, beginning in this period many states amended their constitutions to prohibit incorporation through special act. The dates of these constitutional prohibitions are tabulated in Hamill (1999). 
of one vote per shareholder in director elections. Wisconsin was the only state ever to impose such a rule in its corporation law in the period under study. The legislatures of both Iowa and Wisconsin were controlled by Jacksonian Democrats at the time their general statutes were enacted (Dubin 2007). In one, concerns about corporate privilege led to the adoption of an extraordinarily flexible law, likely intended to produce a rapid proliferation of new corporations that would undermine the exclusivity of corporate privileges. ${ }^{16}$ In the other, those same concerns produced a law with terms so restrictive they bordered on the punitive, which was intended to restrain corporations and their controlling shareholders.

In the 1850s, another fifteen states and territories adopted general acts, including a substantial number of Southern states (among all those that would secede from the United States in the Civil War, only South Carolina and Texas failed to adopt a general incorporation act for manufacturing firms prior to 1860). Many of the statutes adopted during this period, particularly those of western states, incorporated passages from New York's statute, which was revised in 1848 to include a number of provisions intended to protect the interests of creditors. ${ }^{17}$ The laws of Southern states, however, were not as influenced by the New York statute, and were in fact quite different from those of the mid-Atlantic states or the New England states in many respects. Relative to the laws implemented in other regions, Southern states' general acts tended to impose fewer restrictions on the internal governance of corporations. ${ }^{18}$ In addition, some of the Southern statutes included provisions that gave discretion over access to incorporation to a government official. This official, sometimes a judge, the attorney general, or the governor, was given the power to exclude individuals seeking to incorporate a business from doing so, in language that was often much more explicit than that of Pennsylvania's 1836 law. Mississippi's statute, for example, states that "the governor may require amendments to or alterations to be made [to proposed corporations' certificates] ... or if deemed expedient by him, he may withhold his approval entirely." " this a step further by completely excluding particular groups, usually nonwhite persons, from access to their laws. For example, the statute of Georgia applied only to "free white citizens of the State" and the border state of

16. Horack (1904) notes that previous experience with corporate charters in Iowa demonstrated the "evils of special incorporation."

17. These provisions included a limit on firm indebtedness, prohibitions against paying dividends out of the firm's capital or in insolvency, a requirement that the list of shareholders be kept publicly accessible "every day except Sunday and the Fourth of July," and detailed provisions governing procedures by which shareholders could increase or decrease their firms' capital stock.

18. For example, the statutes of both Mississippi and Alabama make no mention of a board of directors or president-incorporators were permitted to choose whether or not to have a board, and if so, to structure it however they wished. Alabama's statute did, however, impose a rule of one vote per share, whereas Mississippi's granted incorporators discretion over the allocation of voting rights.

19. The statutes of Louisiana and Virginia granted similar discretionary powers to judges. 
Maryland's statute prohibited "free negroes and mulattoes" from forming corporations. ${ }^{20}$

Also during the $1850 \mathrm{~s}$, a number of states that adopted general acts in the 1840 s and early 1850 s amended their laws, perhaps motivated by experience with their own statutes, or by legislation enacted in other states. Many of these amendments were focused on limits on capitalization; Tennessee and Illinois imposed such limits for the first time, whereas Connecticut and Massachusetts raised theirs. But there were much more significant changes as well. In 1858, Wisconsin substantially rewrote its corporation laws, removing its unusual provisions of unlimited liability for shareholders and the rule of one vote for each shareholder. And in 1852 Ohio radically revised its corporation laws, with new provisions that eliminated all restrictions on capitalization and board structure, while imposing unlimited liability on shareholders. This revision may have had unintended consequences, as the law was revised again in 1854 , with provisions that restored limited liability to shareholders.

By 1860 , twenty-seven of thirty-two states and organized territories had adopted general incorporation acts. The proliferation of general acts is illustrated in figure 5.1. Although the number of states with a general law remained quite small until the mid-1840s, New York's population was such a large share of the nation's that the fraction of the population living within a state with a general law was around 20 percent after 1811 . The figure clearly illustrates the rapid adoption of these acts after 1845, which caused the fraction of the population living in a state or territory with a general law to increase from about 30 percent to more than 90 percent by 1860 .

There was nonetheless considerable variation across regions in the rate at which general acts were adopted. Figure 5.2 presents the diffusion of general acts within the different regions of the country, with each panel depicting the share of the population of the region residing in states with general acts. Led by New York, the mid-Atlantic states adopted general incorporation much earlier than the other regions. Ohio and Illinois's adoption and repeal of general acts produced early volatility in the pattern for the Midwest, which eventually adopted general acts at high rates beginning in the late 1840 s. By 1860 , nearly 100 percent of the population of both the mid-Atlantic and Midwestern states had access to general incorporation. In contrast, New England stands out as being considerably more resistant to general incorporation than all the other regions. By 1860 only 60 percent of the region's population resided in states with general acts.

The South stands out as adopting general incorporation statutes later than the other regions. There were no early adopters in the South, and the

20. The Georgia statute did, however, authorize the free whites of the state to form corporations with "such others as they may associate with them," which was likely intended to enable them to form corporations with investors from out of the state. 
(a) States and Territories with General Incorporation

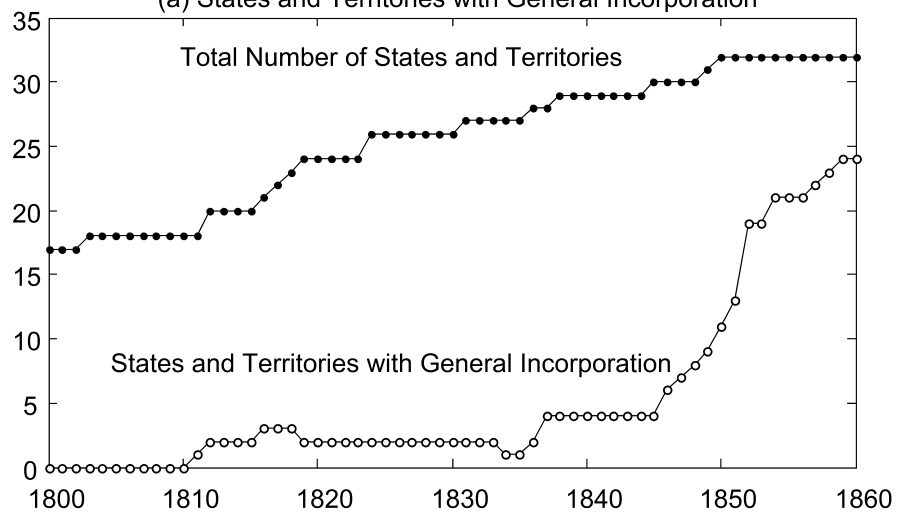

(b) Share of Population Living in States and Territories

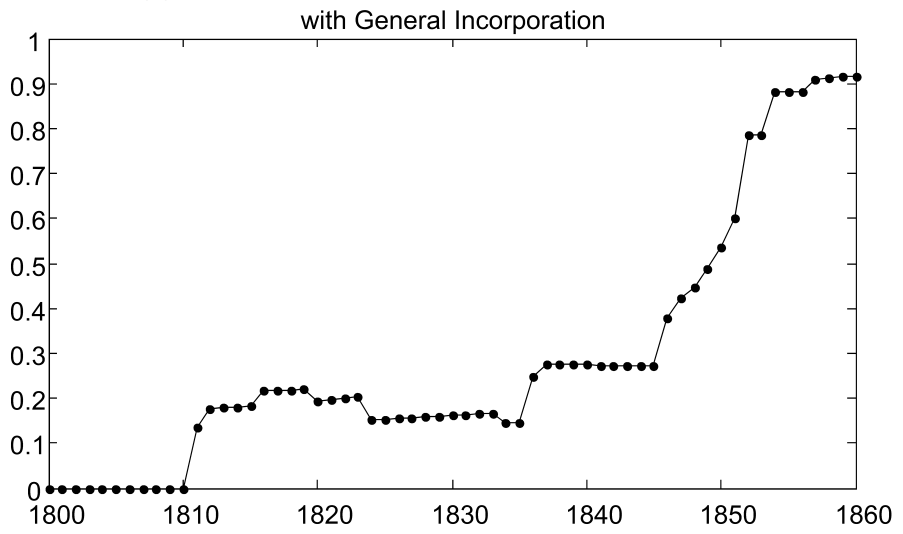

Fig. 5.1 Adoption of general incorporation acts by states and territories

Note: The upper figure presents total states and organized territories included in the most recent decennial census. The lower figure presents the share of total population in states and territories with general incorporation acts for manufacturing enterprises in place. Population levels for individual states linearly interpolated between census years.

first general act there was Georgia's of 1847. As with the Midwest, most of the South's general acts were introduced in the 1850s, and ultimately general incorporation became the norm in the region. By 1860 all but one of the Southern states had made the transition.

\subsection{Political Economy of the Adoption of General Incorporation Acts}

The adoption of a general statute created a significant political transition in which access to incorporation (with important conditions and exceptions) was opened to all entrepreneurs. The state legislature could no longer 
(a) Mid-Atlantic States

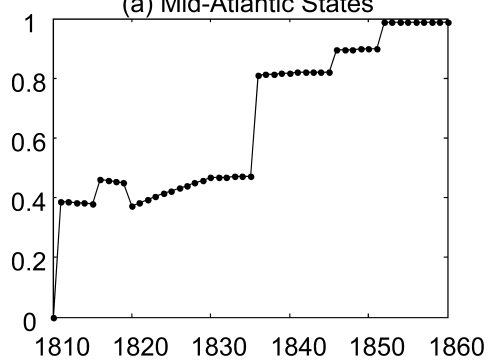

(c) New England States

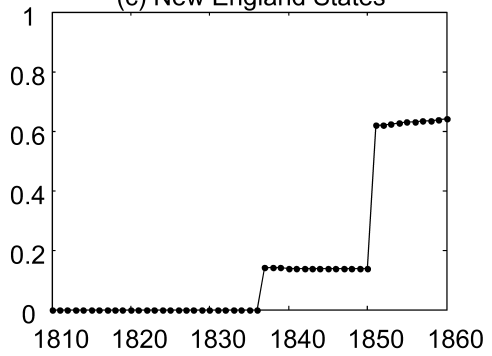

(b) Midwestern States

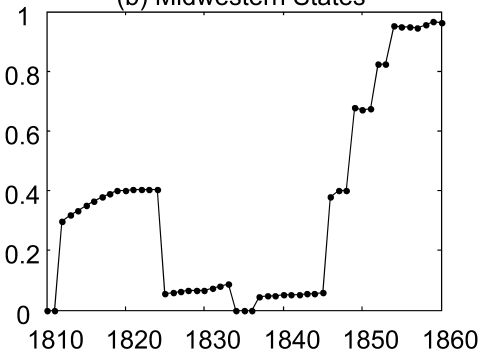

(d) Southern States

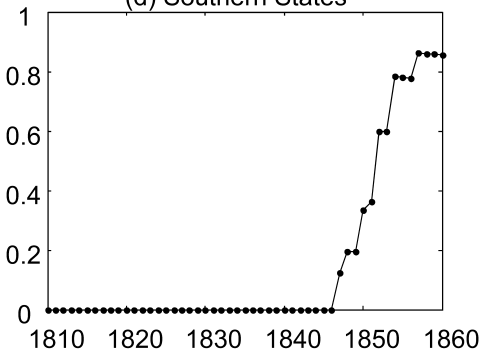

Fig. 5.2 Proliferation of general acts among different regions

Note: The figure presents the share of total population in states and territories with general incorporation acts for manufacturing enterprises in place for each region. The mid-Atlantic states are defined as New York, New Jersey, Pennsylvania, Maryland, and Delaware. Virginia is included among the Southern states, which are defined as those that seceded during the Civil War. Population levels for individual states linearly interpolated between census years.

exercise control over access to the form, except in cases where entrepreneurs sought to create firms that did not conform to the terms of the general statute. In some cases incumbent interests resisted the adoption of general acts for some time, and it took economic and political crises to weaken those interests sufficiently for a general act to be adopted.

The political party most often associated with the adoption of general acts was the Democrats. The Jacksonian anticorruption impulse, which sought to undermine special privileges and vested rights, animated the efforts of the Democrats to push for their adoption. And indeed, at the time when the states finally did implement a general statute, 67 percent of the upper houses of their governments, and 57 percent of their lower houses, had Democratic majorities. Both houses had Democratic majorities 48 percent of the time. ${ }^{21}$

But the ultimate cause of the adoption of a general act, or the failure to adopt one, was not the relative influence of a political party, but the deeper

21. These calculations were made from data presented in Dubin (2007). The calculations were made for the period of the Second Party System (late 1820s until early 1850s). Legislators identified with parties allied with the Democrats, such as the Free Soil Party, were counted as Democrats in the calculations. 


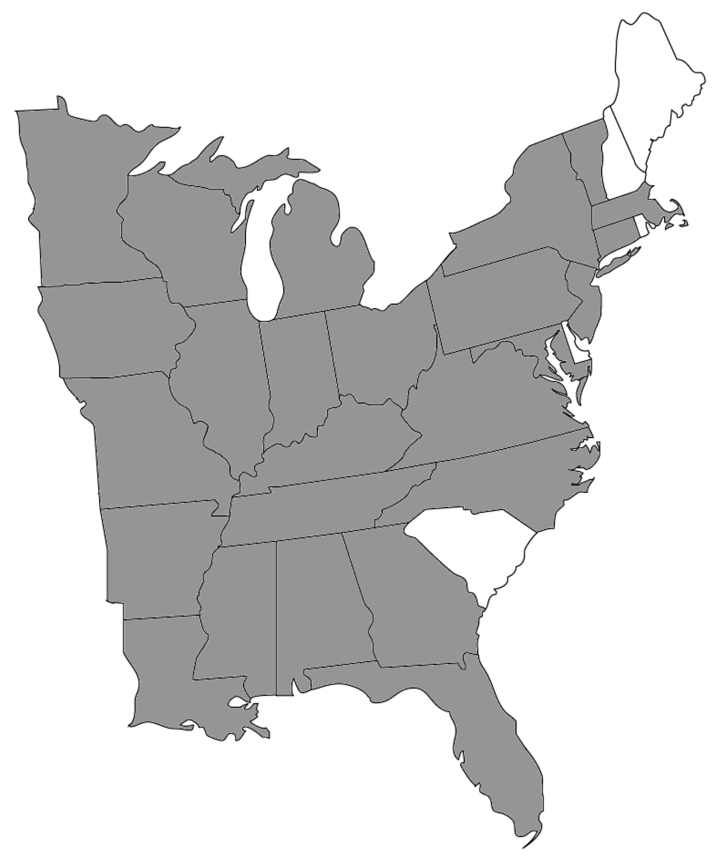

Fig. 5.3 Adoption of general incorporation among the eastern states, 1860

Note: The shaded states are those that had adopted general incorporation for manufacturing enterprises by 1860 . Those that had not adopted general incorporation included Maine, New Hampshire, Rhode Island, Delaware, and South Carolina. States and territories that had adopted general incorporation but are not included in the figure include California and the Kansas Territory.

economic and political forces that led to that political party's ascendance. In order to understand the adoption of general acts, we must therefore analyze the characteristics of the states' social and economic structure that may have contributed to the emergence of political factions friendly to general acts.

Some preliminary insights into the forces influencing the decision to adopt a general act can be obtained by simply looking at a map. Figure 5.3 presents the eastern United States, with the states that had adopted general incorporation by 1860 shaded gray. The near ubiquity of the gray shading in every region of the map illustrates the prevalence of general acts at that time. But there are some states that failed to adopt general incorporation-Maine, New Hampshire, Rhode Island, Delaware, and South Carolina - and they were all located along the coast. Since the structure of economic activity within coastal states was likely somewhat different from that of inland states, this may be an indication that the composition of economic activity influenced whether a state adopted general incorporation. In particular, shipping, trade, and commerce were likely to be more important to coastal economies than inland economies, and these activities may have been par- 
ticularly reliant on commercial credit networks in which personal liability for debts was the norm. If general incorporation was expected to facilitate the creation of large numbers of businesses with limited liability that would seek to attract credit from banks and other lenders, then existing commercial borrowers may have feared that their access to credit would deteriorate as a result. ${ }^{22}$ The adoption of a general incorporation law may therefore have been perceived to risk disrupting the credit networks that were so essential to the operations of commerce.

With the exception of South Carolina, the states that failed to adopt general incorporation were also relatively small. Perhaps in a small state, the costs associated with obtaining special charters, and therefore the benefits of the transition to general incorporation, were somewhat lower. Certainly the expenses associated with traveling to the state capital to petition the legislature would have been lower; perhaps businesspeople were also more likely to have regular personal contact with legislators as well, which might also have made special charters more accessible.

The small size of a state may also have influenced its behavior toward granting corporate charters through the forces of jurisdictional competition. The small states that failed to adopt general incorporation were located near large, economically important states such as Massachusetts, New York, or Pennsylvania. At the time, corporations could not easily operate in states that had not granted them charters, ${ }^{23}$ but entrepreneurs and investors could relocate their firms to nearby states or invest in firms located in other states. Small states, whose markets were of limited size, would have felt this threat most acutely, and may therefore have been inclined to be quite liberal in their grants of corporate charters. And if these pressures induced small states to offer generous access to corporate charters, the benefits of a transition to general incorporation would have been smaller. This also suggests that general incorporation statutes were not the only available response to jurisdictional competition; liberal access to special charters might also address this issue. ${ }^{24}$

22. At a minimum, the emergence of large numbers of new borrowers would have driven up the cost of borrowing for incumbents. But if the new entrants were expected to be of lower "quality" or higher risks, and if lenders were potentially unable to clearly distinguish among the quality of various borrowers, perhaps because of their large incorporated capitals, then incumbent borrowers might have suffered the consequences of increased adverse selection in credit markets.

23. At the time, states' laws discriminated against "foreign" corporations in various ways (see, e.g., Henderson 1918); corporations that operated in multiple states, such as large canals or railroads, typically were incorporated in all the states in which they operated. The modern form of jurisdictional competition, which results from businesses' freedom to incorporate in any state, irrespective the location of their operations, did not exist in the antebellum United States.

24. Butler (1985) argues that jurisdictional competition in the era when businesses could incorporate in any state led to the adoption of liberal general incorporation statutes. The analysis of this chapter suggests that the mobility of capital in the early nineteenth century may have influenced states' willingness to grant special charters, and thereby slowed the adoption of general statutes. 
Another mechanism by which the size of a state may have influenced its propensity to adopt a general act is modeled by Mulligan and Shleifer (2005), which formalizes an idea due to Demsetz (1967). If imposing new regulations has fixed costs, then the supply of regulation is limited by the extent of the market or the size of the state. If there was a fixed cost associated with implementing and administering a general statute, this could explain the small states' reluctance to adopt such legislation. Note, however, that this hypothesis should be related more closely to population size rather than geographical area, an implication that can be tested empirically.

Other elements of a state's economic and social structure may also have influenced its propensity to adopt general laws. For example, agrarian interests, while not necessarily hostile to manufacturing, may have regarded limited liability corporations as potentially disruptive financially and opposed a transition to open access to the corporate form. States with a larger share of their population engaged in agriculture may therefore have been more likely to resist the adoption of a general statute. In addition, some states may have developed stronger associational cultures or institutions that encouraged participation in political or economic organizations, or reform movements. Those states would have been more likely to adopt statutes that facilitated access to the corporate form. Finally, the importance of slavery in a state's economy may have influenced the openness of its institutions (Engerman and Sokoloff 2002), and perhaps its political system's willingness to make the corporate form openly accessible to the population.

We can begin to investigate these hypotheses more carefully by comparing various characteristics of states that did and did not adopt general incorporation by 1860 . In order to avoid the potential for general incorporation acts to influence the measures of economic and social structures under analysis, these data will be taken from the year 1840, before most states had adopted general acts. It should be noted that this will restrict the sample of states to those for which census data is available in $1840 .{ }^{25}$

Simple comparisons of means are presented in table 5.2. The data in the first three rows of the table offer statistical confirmation that small states, both in terms of geographical area and population, were less likely to adopt general incorporation acts, and that states located along the Atlantic seaboard were also less likely to adopt such laws. The data in the fourth row, which presents the total number of special charters granted to businesses up to 1840 , scaled by 1840 population, indicate that the states that did not adopt general incorporation acts were far more liberal in granting charters to businesses. The mean among those that did not adopt general acts, 0.117 charters per 100 persons, was more than twice as high as that of the states that did adopt general acts ( 0.052 charter per 100 persons), and the differ-

25. This results in the exclusion of Texas, California, Minnesota, and Kansas from the analysis. Of these, only Texas failed to adopt a general act prior to 1860 . 
Table 5.2

Characteristics of states that did and did not adopt general laws prior to 1860

\begin{tabular}{lccc}
\hline & $\begin{array}{c}\text { States that did } \\
\text { not adopt general } \\
\text { statutes by } 1860\end{array}$ & $\begin{array}{c}\text { States that did } \\
\text { adopt general } \\
\text { statutes by } 1860\end{array}$ & $\begin{array}{c}\text { Difference } \\
(3)\end{array}$ \\
\hline Area (square miles) & $(1)$ & $(2)$ & $-29,089^{* * *}$ \\
Population, 1840 & 16,156 & 45,246 & $(8,202)$ \\
Location: Atlantic & $(7,307)$ & $(4,559)$ & $-330,297^{* *}$ \\
seaboard & $(103,078)$ & 643,833 & $(153,353)$ \\
Charters granted per & 1.000 & 0.417 & $0.449^{* *}$ \\
100 persons, 1840 & $(0)$ & $(0.103)$ & $(0.186)$ \\
Share population in & 0.117 & 0.052 & $0.065^{* *}$ \\
agriculture, 1840 & $(0.030)$ & $(0.008)$ & $(0.029)$ \\
Enslaved people per & 0.235 & 0.230 & 0.004 \\
capita, 1840 & $(0.031)$ & $(0.012)$ & $(0.031)$ \\
\hline
\end{tabular}

Sources: Total charters allocated to businesses are from Sylla and Wright (2013). Data for the total population, the share of the population in agriculture, and the number of enslaved people are from the federal census of 1840 . States and territories that were not organized in 1840 or were not included in the 1840 census are not included in the table.

Note: A total of twenty-nine states are included in the table. Standard errors are reported in parentheses. The standard errors in column (3) are calculated from a regression with robust standard errors.

***Significant at the 1 percent level.

**Significant at the 5 percent level.

*Significant at the 10 percent level.

ence is highly statistically significant. Apparently, the legislatures of these states retained discretion over access to the corporate form only in a very limited sense, as entrepreneurs seeking charters were generously accommodated. In such states, the need for fundamental reform of the chartering process through a general act would have been perceived as less acute, as the scope for corrupt influence was likely quite narrow in an environment in which charters were granted to the vast majority of petitioners. ${ }^{26}$

The remaining rows of table 5.2 present data on economic structure. These data indicate that states that failed to adopt general incorporation were not statistically different from those that did, in the shares of their populations engaged in agriculture, and in the importance of slavery in their econo-

26. An alternative interpretation of the correlation between high numbers of charters and the lower propensity to adopt general incorporation is that the large numbers of businesses operating under those charters constituted a powerful interest group that resisted the transition to general incorporation and the new competition it would have created. However, the high rate at which the legislatures of those states apparently granted charters casts some doubt on this interpretation: incumbent corporations seeking to block access to the corporate form should have blocked access to charters, as well as general acts. 
mies (measured as enslaved persons as a fraction of the total population in 1840). The variation in these characteristics of states, however, had a strong regional component, and in order to investigate their influence on states' propensity to adopt general statutes one should focus on the variation within regions. Moreover, outcomes such as the volume of charters granted may be interrelated with states' economic structure, or with other state characteristics such as the number of years they have been organized as states, which may have independently influenced the adoption of general incorporation acts.

In order to isolate the relative importance of these and other potential influences on states' adoption of general acts, I therefore estimate simple linear probability models. An indicator for whether or not the state adopted a general incorporation act prior to 1860 is used as the dependent variable. ${ }^{27}$ Summary statistics of the data are presented in table 5.3, panel A. In addition to the variables examined above, the data include several other state characteristics, such as an indicator for statehood prior to 1800; a measure of the number of newspapers per capita, which might have helped facilitate the flow of political information; and the percentage of the population engaged in commerce, which as stated above was likely negatively correlated with the propensity to adopt general incorporation.

The results of this analysis are presented in table 5.3, panel B. All of the estimated specifications include region fixed effects. Column (1) presents regressions that include only measures of the size, location, and age of the states. These results indicate that the measure of the size of a state that influenced the adoption of a general act was its geographical size, and not the size of its population. ${ }^{28}$ This may be an indication that in states that encompassed smaller areas, the costs of obtaining a special charter, and therefore the benefits of a general corporation statute, were indeed lower. States whose populations were small (conditional on the size of their geographical area, and on their location and age) were no less likely to adopt general acts. This contradicts the hypothesis regarding the role of fixed costs of regulations. The results also indicate that states located on the Atlantic

27. The fact that a few states had already adopted general incorporation prior to 1840 would present a problem for this analysis, if their acts resulted in substantial changes in some of the variables included in the regression. Among the states that had previously adopted general incorporation, two repealed their statutes, and another three adopted them only a few years before 1840 . Only New York, with its long history of operation under general laws, presents a serious problem, and excluding New York from the analysis does not change the results significantly.

28. It is worth noting that one of these small states, Delaware, is the leading choice for firms incorporated away from the states in which they are located. The small size of the state has been proposed as a form of a hostage that the state can offer to corporations, to make a commitment to continually maintain favorable statutes credible (Romano 1985; Grandy 1989). It is possible that a similar mechanism may have operated in the nineteenth century-small states such as Rhode Island and Delaware may have been able to commit to a more favorable special chartering regime. 


\begin{tabular}{|c|c|c|c|c|}
\hline & Mean & $\mathrm{SD}$ & Min. & Max. \\
\hline \multicolumn{5}{|c|}{ A. Summary statistics } \\
\hline General incorporation act adopted prior to 1860 & 0.82 & 0.39 & 0 & 1 \\
\hline Log area (square miles) & 10.259 & 1.053 & 7.343 & 11.480 \\
\hline Log population, 1840 & 12.825 & 1.095 & 10.339 & 14.703 \\
\hline Location: Atlantic seaboard & 0.517 & 0.509 & 0 & 1 \\
\hline Statehood prior to 1800 & 0.552 & 0.506 & 0 & 1 \\
\hline Charters per 100 persons, 1840 & 0.06 & 0.05 & 0.01 & 0.19 \\
\hline Newspapers per 100 persons, 1840 & 0.01 & 0.00 & 0.00 & 0.02 \\
\hline Share of population employed in agriculture, 1840 & 23.09 & 6.10 & 11.91 & 37.20 \\
\hline Share of population employed in commerce, 1840 & 0.69 & 0.47 & 0.22 & 2.43 \\
\hline \multirow[t]{2}{*}{ Share of population enslaved, 1840} & 15.80 & 19.75 & 0 & 55.02 \\
\hline & (1) & (2) & (3) & \\
\hline \multicolumn{5}{|c|}{ B. Regression analysis of whether a state adopted a general incorporation act prior to 1860} \\
\hline \multirow[t]{2}{*}{ Log area (square miles) } & $0.206^{* *}$ & & $0.186^{*}$ & \\
\hline & $(0.095)$ & & $(0.107)$ & \\
\hline \multirow[t]{2}{*}{ Log population, 1840} & 0.008 & & 0.0186 & \\
\hline & $(0.042)$ & & $(0.061)$ & \\
\hline \multirow[t]{2}{*}{ Location: Atlantic seaboard } & $-0.379 *$ & & $-0.484 * *$ & \\
\hline & $(0.189)$ & & $(0.199)$ & \\
\hline \multirow[t]{2}{*}{ Statehood prior to 1800} & 0.224 & & $0.380 * *$ & \\
\hline & $(0.190)$ & & $(0.169)$ & \\
\hline \multirow[t]{2}{*}{ Charters granted per 100 persons, 1840} & & $-6.178^{* *}$ & -3.878 & \\
\hline & & $(2.265)$ & $(2.410)$ & \\
\hline \multirow[t]{2}{*}{ Newspapers per capita, 1840} & & $39.610^{* *}$ & $47.640^{*}$ & \\
\hline & & $(17.790)$ & $(22.590)$ & \\
\hline \multirow[t]{2}{*}{ Share of population in agriculture, 1840} & & $-0.041 * *$ & $-0.050 * * *$ & \\
\hline & & $(0.018)$ & $(0.016)$ & \\
\hline \multirow[t]{2}{*}{ Share of population in commerce, 1840} & & $-0.158^{*}$ & $-0.218 * * *$ & \\
\hline & & $(0.080)$ & $(0.069)$ & \\
\hline \multirow[t]{2}{*}{ Enslaved people per capita, 1840} & & 0.002 & 0.006 & \\
\hline & & $(0.007)$ & $(0.006)$ & \\
\hline \multirow[t]{2}{*}{ Constant } & -1.130 & $1.670 * * *$ & -0.339 & \\
\hline & $(1.180)$ & $(0.303)$ & $(0.875)$ & \\
\hline Observations & 29 & 29 & 29 & \\
\hline$R$-squared & 0.435 & 0.494 & 0.706 & \\
\hline Region FE & YES & YES & YES & \\
\hline
\end{tabular}

Note: Robust standard errors in parentheses.

$* * *$ Significant at the 1 percent level.

** Significant at the 5 percent level.

*Significant at the 10 percent level. 
seaboard were indeed less likely to adopt general acts, even controlling for their age, size, and region.

The second column in the panel presents the results of regressions that include only variables measuring the states' social and economic structure. As expected, the number of charters per capita previously granted to business corporations in a state was negatively associated with the adoption of a general act, and the number of newspapers per 100 persons was positively associated with adoption of an act. Also as expected, the fraction of the population engaged in agriculture was negatively associated with the adoption of a general act, as was the fraction of the population engaged in commerce - the only available measure of the importance of trade and distribution in a state's economy. The fact that these latter estimates are statistically significant, whereas the raw comparisons of means were not, is a reflection of the effect of controlling for states' prior grants of corporate charters. Only conditional on chartering behavior does economic structure matter. Finally, the regression in column (2) also includes the number of slaves as a percentage of the states' total population. The estimated effect is positive but small and insignificant, indicating that slavery and the adoption of general statutes were not strongly related.

Finally, in column (3) of the panel, the variables from the specifications of both columns (1) and (2) are included together, in order to determine whether the influence of the variables in column (1), which measured states' size, location and age, was due to their relationship to states' economic performance, or whether they exerted some independent influence. For the most part, the inclusion of both sets of variables does not radically alter the size and significance of the estimated effects; most of the parameters are of similar size and levels of significance. This suggests that these different categories of variables exerted at least partially independent influences on states' adoption of general acts. That is, even though small states were older and more likely to have a particular economic structure, the effect of state size on the propensity to adopt a general act is important even conditional on its economic structure. The major exception is states' previous grants of charters. Conditional on states' size and location, the effect of this variable on states' adoption of general acts is diminished significantly. Apparently the estimated effect in column (2) was mainly due to the fact that small states located along the Atlantic seaboard granted larger numbers of charters. Another estimate that changes in magnitude to an important extent is the indicator for the age of a state, which increases significantly.

These results clearly indicate that a state's economic structure influenced its probability of adopting general incorporation, but other forces related to geography, and perhaps politics, mattered as well. States with large commercial and agricultural sectors were less likely to make the transition, whereas those with large numbers of newspapers were more likely to make the transition. In addition, smaller states, states located along the Atlantic seaboard, 
and younger states were all less likely to adopt general incorporation. The effect of a state's size may have influenced the costs of acquiring a special charter, and, through the forces of jurisdictional competition, the willingness of a state to accommodate requests for special charters.

Among those small states that failed to adopt general incorporation, grants of special charters were quite generous. This suggests that in practical terms access to incorporation may not have been dramatically greater in states that adopted general incorporation relative to those that did not. Although general acts almost certainly did improve access to the corporate form, the states that failed to adopt those acts were a highly selected group that granted corporate charters quite liberally. Researchers seeking to analyze the effect of general acts or to use general acts as indications of liberal access to the corporate form must take care to account for the selected nature of the states adopting such laws. ${ }^{29}$

\subsection{The Choice of Terms of General Incorporation Acts}

As the discussion of the history of general incorporation statutes in section 5.2 made clear, there was substantial variation in the terms of the laws enacted by different states. Some were generally quite prescriptive, whereas others granted entrepreneurs greater freedom to configure their enterprises as they wished. Some imposed regulations intended to protect the rights of creditors or give the state a measure of control over the enterprise, whereas others included fewer such terms. And some states restricted access to their laws in various ways, sometimes to such an extent that their laws cannot truly be said to have facilitated open access to the corporate form. The transition to general incorporation was not a simple binary choice, but rather a complex array of choices made by legislators. In order to understand the impact and significance of these statutes, it is necessary to understand what was in them and how and why their terms varied across states.

Without much more detailed and specific knowledge of nineteenthcentury enterprise management and legal practice, it is not possible to conclusively identify which of the terms of these laws were the most important or onerous to contemporary entrepreneurs. In addition, the language of the statutes was subject to judicial interpretations, which may have magnified or minimized their practical importance. ${ }^{30}$ What follows is a descriptive char-

29. In particular, any simple cross-sectional comparison will likely understate the effects of a general act, since the states that failed to adopt general incorporation - and therefore constitute the comparison or "control" group of any study - offered liberal access to the corporate form, whereas those that adopted general acts in some cases were much more restrictive in their corporate chartering.

30. An important example is the issue of stockholder liability. New York's 1811 act stated that "the persons . . . composing such company shall be individually responsible to the extent of their respective shares of stock in the said company, and no further." This slightly ambiguous language was interpreted in different ways by contemporaries, but New York's courts eventually held that the shareholders faced double liability (Howard 1938). 
acterization of the text of the states' general incorporation acts, as amended in 1860. Simple tabulations of important terms are used to document the variation in the substance of general acts across states, as well as to analyze the determinants of the states' choices of the terms of their laws.

Most states' general acts included at least some restrictions on the governance institutions of firms. These were likely intended to ensure that the interests of investors were adequately represented in the management of the corporations, but they may have had the effect of constraining the corporations in other ways as well. ${ }^{31}$ Table 5.4, panel A, presents summary statistics for a series of simple indicator variables summarizing common restrictions imposed on firms' internal governance in general acts. In 67 percent of these laws, the corporations were specifically required to have a president, and 59 percent of the time, the statutes specified a particular configuration of voting rights for shareholders. Also 59 percent of the time, the size of the board of directors was restricted, either with a minimum number of members, a maximum, or both. The table panel also includes summary statistics for these variables by region; with each, there is relatively little variation across regions, except in the South, whose statutes look quite different from those of the rest of the country. In particular, the general acts of Southern states were far less likely to impose these restrictions, and for two of the three variables the difference is highly significant.

Most general acts also included provisions intended to protect the creditors of corporations, and table 5.4, panel B, presents summary data for several important examples of these. Limits on leverage - usually expressed as a rule that the total debts of a corporation could not exceed its capital, or some multiple of its capital-were imposed 48 percent of the time. Annual reports, whose content varied substantially across states but typically stated the firms' paid-in capital and total debts, were required 55 percent of the time $^{32}$ Around a third of the statutes prohibited loans to stockholders, which could be used by unscrupulous insiders to withdraw their investment in the firm and weaken its capitalization. And 20 percent of the statutes required shareholders' contributions to the firms' capital to be in cash. Only two of the twenty-seven states imposed some form of unlimited liability on stockholders in 1860 — California and Minnesota. ${ }^{33}$ Thirty-seven percent of

31. For example, a substantial literature has developed that analyzes the purpose and effects of rules dictating particular configurations of stockholder voting rights within early corporations. On their political significance, see Dunlavy (2004); see Hansmann and Pargendler (2010) on their effects on consumers. Hilt (2013) presents a synthesis.

32. Often these reports were required to be published in a local newspaper or submitted to the state government. Many states also required that the board of directors "make a report" to the stockholders at the corporations' annual meetings.

33. Two states, Wisconsin and Ohio, imposed unlimited liability in earlier statutes, but then amended them prior to 1860 . In addition, thirteen states imposed unlimited liability on shareholders for debts to employees, and most states stripped directors of their limited liability in cases of fraud or violation of other prohibitions such as those against loans to stockholders or debts in excess of their capital. 


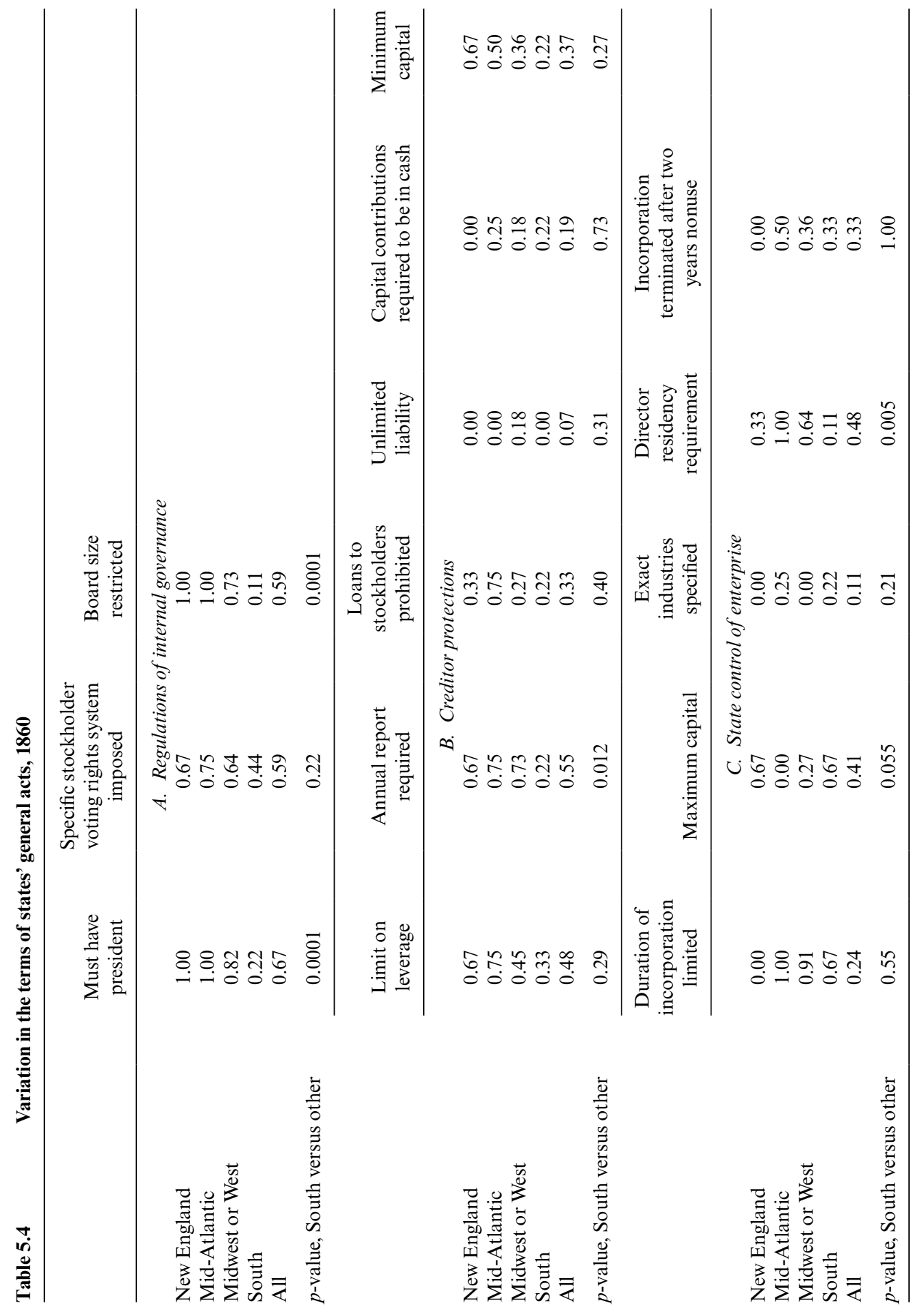


Terms of states' general acts, 1860

\begin{tabular}{lccccc}
\hline & $\begin{array}{c}\text { Governance } \\
\text { restrictions } \\
(1)\end{array}$ & $\begin{array}{c}\text { Creditor } \\
\text { protections } \\
(2)\end{array}$ & $\begin{array}{c}\text { State } \\
\text { control } \\
(3)\end{array}$ & $\begin{array}{c}\text { Exclusions } \\
(4)\end{array}$ & $\begin{array}{c}\text { Total } \\
\text { restrictions } \\
(5)\end{array}$ \\
\hline New England & \multicolumn{2}{c}{ A. Summary measures } & & & \\
Mid-Atlantic & 2.67 & 2.33 & 1.00 & 0.00 & 6.00 \\
Midwest or West & 2.75 & 3.00 & 2.75 & 0.25 & 8.75 \\
South & 2.18 & 2.18 & 2.18 & 0.00 & 6.54 \\
All: Mean & 0.78 & 1.22 & 2.00 & 0.56 & 4.55 \\
$\quad$ Standard deviation & 1.85 & 2.00 & 2.07 & 0.22 & 6.14 \\
$\quad$-value, South versus other & $(1.17)$ & $(1.33)$ & $(0.95)$ & $(0.42)$ & $(2.58)$ \\
& 0.002 & 0.029 & 0.78 & 0.002 & 0.020 \\
Governance restrictions & 1.000 & B. Correlations & & & \\
Creditor protections & 0.545 & 1.000 & & & \\
State control measures & 0.423 & 0.271 & 1.000 & & \\
Exclusions & -0.476 & -0.205 & -0.232 & 1.000 & \\
\hline
\end{tabular}

the statutes imposed some minimum capitalization on firms. There is some regional variation in the frequency with which these rules were imposed, and in general, Southern states were somewhat less likely to impose them. But the differences between the South and the North are not nearly as strong as with the governance provisions.

A third category of provisions of general acts circumscribed the powers of corporations in various ways, and are perhaps best characterized as measures intended to ensure some degree of control by the state over the corporation. These are presented in table 5.4, panel C. For example, 24 percent of the laws limited the duration of the incorporation. The average value of this limit was 39.5 years. In 41 percent of the laws, a maximum capitalization was imposed, which in most cases ensured that firms wishing to reach a very large scale had to seek a charter from the state. Only 11 percent of the statutes specifically listed the industries that could be pursued by firms incorporated under the act, and 48 percent of the statutes required some fraction of the corporations' directors to be residents of the state. Finally, a third of the laws included a condition that if the firm failed to commence operations within two years, its status as a corporation would be terminated. Among these state control provisions, there is far less of a discernible regional pattern. Southern states were less likely to impose some of these provisions, but with most there is no meaningful difference.

Table 5.5, panels A and B, present statistics for aggregations of these variables. That is, each summary variable is defined as the sum of the components within its corresponding panel of table 5.4, but it includes two additional summary variables as well. The first is termed "exclusions." Two of the states, Georgia and Maryland, specifically restricted access to their statutes 
to free white persons. These exclusions may have been motivated by a desire to preserve the social and economic order, and ensure that nonwhites were not able to form business corporations that could potentially elevate their economic and social status. However, they may also have been motivated by a desire to prevent nonwhites from creating organizations that would enable them to associate and that enjoyed legal protections from state interference. ${ }^{34}$ Another four states imposed a rule that the certificates of entrepreneurs wishing to incorporate their firms were not automatically recorded, but were instead scrutinized by some public official. Although these measures could in principle be used to simply ensure compliance with the terms of the statute, they also gave the state the authority to exclude groups, such as nonwhites, from access to the corporate form. As table 5.5, panel A, makes clear, the South was quite different from the rest of the country in the degree to which it included these exclusionary terms in its laws.

In addition, column (5) of table 5.5, panel A, includes summary data for a variable called total restrictions in act, which is defined as the sum of the entries in columns (1) through (4). This is an ad hoc measure of the overall degree of restrictiveness of a state's corporation law. It should not be interpreted as a true measure of the restrictiveness of a state's law, since it imposes equal weights on all of the provisions, whereas some were undoubtedly much more important than others. Even though the Southern states were more likely to impose exclusions in their laws, their overall level of total restrictions was lower than that of any other region, and the difference is statistically significant. Southern states' laws generally offered incorporators more freedom in the design and operation of their enterprises.

Table 5.6 displays the value of this measure for each of the twenty-seven states with general acts in 1860 , organized by region. Although the small numbers of individual states make comparisons difficult, the New England and mid-Atlantic states are much more uniform in the degree of stringency of their laws, as indicated by the total number of restrictions in their acts. In contrast, there is considerable variation within the states grouped as the "Midwest and West," with Kentucky, Michigan, and Illinois's laws being quite different from those of Iowa, Kansas, and Ohio. In the South, with the exception of the outlier Tennessee, the statutes were quite unrestrictive.

Some of the different categories of restrictions may have served as substitutes for one another. One might imagine, for example, that a statute that imposed a strong degree of creditor protections might have been perceived as needing fewer measures to ensure that the state had adequate control over the enterprise. But table 5.5, panel B, presents the simple correlations among these provisions, and shows that they are almost always positive. That is, states with a higher level of governance restrictions tended to also have a

34. Southern states, in fact, restricted blacks from associating in numbers in the absence of white observers. See the discussion in Brooks and Guinnane (2014). 

Index of restrictiveness of states' general acts, 1860

\begin{tabular}{|c|c|}
\hline State & Total restrictions in general act \\
\hline \multicolumn{2}{|l|}{ New England } \\
\hline Connecticut & 6 \\
\hline Massachusetts & 6 \\
\hline Vermont & 6 \\
\hline \multicolumn{2}{|l|}{ Mid-Atlantic } \\
\hline Maryland & 9 \\
\hline New Jersey & 8 \\
\hline New York & 8 \\
\hline Pennsylvania & 10 \\
\hline \multicolumn{2}{|l|}{ South } \\
\hline Alabama & 4 \\
\hline Arkansas & 4 \\
\hline Florida & 4 \\
\hline Georgia & 5 \\
\hline Louisiana & 3 \\
\hline Mississippi & 4 \\
\hline North Carolina & 2 \\
\hline Tennessee & 10 \\
\hline Virginia & 5 \\
\hline \multicolumn{2}{|l|}{ West } \\
\hline California & 8 \\
\hline Illinois & 10 \\
\hline Indiana & 6 \\
\hline Iowa & 2 \\
\hline Kansas & 3 \\
\hline Kentucky & 8 \\
\hline Michigan & 8 \\
\hline Minnesota & 6 \\
\hline Missouri & 10 \\
\hline Ohio & 3 \\
\hline Wisconsin & 8 \\
\hline
\end{tabular}

higher degree of creditor protections and also a greater number of state control measures. This could be a sign that some state governments took a consistently more restrictive stance toward corporations than others. However, it could also be a sign that with experience, some states produced more detailed corporation statutes that covered a broader range of contingencies and included more detailed regulations. The one exception to this pattern of positive correlations is with the exclusions, which are negatively correlated with all of the other measures. Perhaps the Southern states were willing to grant broad freedoms to entrepreneurs, so long as they could ensure that those entrepreneurs did not include free blacks or other elements of their society who could potentially threaten the stability of their social order if they were empowered to create corporations. 
Table 5.7

Determinants of states' general act terms

\begin{tabular}{|c|c|c|c|c|}
\hline & \multicolumn{2}{|c|}{ Governance restrictions } & \multicolumn{2}{|c|}{ Creditor protections } \\
\hline & (1) & (2) & (3) & (4) \\
\hline Charters per 100 persons & $\begin{array}{c}9.266^{*} \\
(5.126)\end{array}$ & $\begin{array}{c}3.495 \\
(5.866)\end{array}$ & $\begin{array}{c}7.622 \\
(5.888)\end{array}$ & $\begin{array}{c}3.497 \\
(6.431)\end{array}$ \\
\hline Years since first general act & $\begin{array}{l}0.0466^{* *} \\
(0.0171)\end{array}$ & $\begin{array}{c}0.0175 \\
(0.0117)\end{array}$ & $\begin{array}{c}0.0252 \\
(0.0229)\end{array}$ & $\begin{array}{c}0.00448 \\
(0.0197)\end{array}$ \\
\hline South & & $\begin{array}{l}-1.472 * * * \\
(0.499)\end{array}$ & & $\begin{array}{c}-1.052 \\
(0.679)\end{array}$ \\
\hline Constant & $\begin{array}{c}0.749 \\
(0.514)\end{array}$ & $\begin{array}{l}1.977^{* * *} \\
(0.661)\end{array}$ & $\begin{array}{l}1.235^{* *} \\
(0.572)\end{array}$ & $\begin{array}{l}2.113^{* *} \\
(0.799)\end{array}$ \\
\hline \multirow[t]{3}{*}{$R$-squared } & $\begin{array}{c}24 \\
0.229\end{array}$ & $\begin{array}{c}24 \\
0.506\end{array}$ & $\begin{array}{c}24 \\
0.082\end{array}$ & $\begin{array}{c}24 \\
0.192\end{array}$ \\
\hline & \multicolumn{2}{|c|}{ State control measures } & \multicolumn{2}{|c|}{ Exclusions } \\
\hline & (1) & (2) & (3) & (4) \\
\hline Charters per 100 persons & $\begin{array}{l}-6.800^{* *} \\
(3.110)\end{array}$ & $\begin{array}{l}-8.490^{* *} \\
(3.287)\end{array}$ & $\begin{array}{l}-2.080 \\
(1.425)\end{array}$ & $\begin{array}{c}-0.318 \\
(1.420)\end{array}$ \\
\hline Years since first general act & $\begin{array}{c}0.0177 \\
(0.0130)\end{array}$ & $\begin{array}{r}0.00917 \\
(0.0154)\end{array}$ & $\begin{array}{l}-0.0133^{*} \\
(0.00693)\end{array}$ & $\begin{array}{c}-0.00442 \\
(0.00520)\end{array}$ \\
\hline South & & $\begin{array}{c}-0.431 \\
(0.460)\end{array}$ & & $\begin{array}{c}0.449^{* *} \\
(0.209)\end{array}$ \\
\hline Constant & $\begin{array}{l}2.293^{* * *} \\
(0.391)\end{array}$ & $\begin{array}{l}2.652^{* * *} \\
(0.487)\end{array}$ & $\begin{array}{l}0.530^{* *} \\
(0.198)\end{array}$ & $\begin{array}{c}0.155 \\
(0.160)\end{array}$ \\
\hline Observations & 24 & 24 & 24 & 24 \\
\hline$R$-squared & 0.116 & 0.153 & 0.115 & 0.306 \\
\hline
\end{tabular}

Note: Robust standard errors in parentheses.

***Significant at the 1 percent level.

**Significant at the 5 percent level.

*Significant at the 10 percent level.

On the other hand, the distinctive pattern of less restrictive corporation laws among the Southern states could simply reflect the fact that those states had far less experience with the corporate form since they had chartered relatively small amounts of corporations prior to 1840 (see table 5.2). They also adopted general acts at later times than states in other regions (see figure 5.2), so in addition to having less experience with administering and refining their law, they may have been influenced by any trend toward more permissive statutes that could have been present in the late 1850s.

In order to disentangle these two potential explanations for the permissive nature of the Southern statutes, table 5.7 presents a series of simple regressions in which the relationships between the statutes' characteristics and 
the states' level of corporate charters in 1840 and years of experience with its general act are estimated. These regressions are then repeated with the inclusion of a regional fixed effect for the South. If the differences between the South and the North are simply due to the timing of the South's acts or their infrequent grants of charters prior to 1840 , then the patterns within the South and within the North of states with similar levels of charters in 1840 and years of experience with general laws should be the same-the inclusion of the South fixed effect should not reduce the estimated effect of those variables. If, however, the South is different for other reasons, then the South fixed effect should dominate.

The results in table 5.7 indicate that with respect to governance provisions, the South was genuinely unique. The estimated relationship between the level of charters in 1840 and years of experience with a general act is completely transformed with the inclusion of the Southern fixed effect, which is estimated to be negative and large. With creditor protections the estimated relationships are similar, but the coefficients are smaller and less precisely estimated. Southern states were unique in this respect as well, but the difference was not so sharp.

On the other hand, the estimated relationship between 1840 charters and years of experience with the state control measures included in general acts is quite robust to the inclusion of the South fixed effect. Those regressions clearly indicate that the states that had previously granted large numbers of charters were considerably less likely to include as many state control measures in their laws, and that relationship holds within the North and South. The states that already had large numbers of corporations felt it less necessary to circumscribe the powers of new corporations' in their general acts.

Finally, with regard to the exclusions, unsurprisingly the South was quite unique. Relative to other states that adopted their general acts relatively late, Southern states were far more likely to impose such measures.

With regard to many of the terms of general acts, then, there were significant differences between Northern and Southern states, and these appear not to be driven simply by the different timing of Southern states' adoption of their laws, or the lack of experience with chartered corporations in the South. The general acts of Southern states were less restrictive than those of Northern states, perhaps because they were much more likely to exclude access to their terms to elements of society over which they wished to retain control.

\subsection{Conclusion: General Incorporation Acts and the Transition to Open Access}

Over the course of the nineteenth century, business corporations became increasingly important within the American economy, and ultimately transformed economic life. The states' general incorporation acts facilitated the 
creation of the majority of these corporations and regulated their governance, capital structure, and operations. This chapter has documented the earliest general acts for manufacturing corporations in the United States and the terms they contained. It also analyzed the political, economic, and social forces that influenced the decision to adopt or resist general acts. Several distinct insights follow from the analysis.

First, many states adopted general acts far earlier than has previously been documented. Following New York's 1811 act, the states of New Jersey, Ohio, and Illinois adopted similar acts, although all three of the latter statutes were eventually repealed. Other states, including Georgia and Missouri, first adopted general incorporation acts somewhat later, in the 1840s, but this was several decades earlier than previous scholarship has indicated. Ascertaining the extent to which any of these statutes were actually utilized, and the reasons for the repeal of many of the early acts, will require further research. But these laws may have opened access to the corporate form, at least in a formal legal sense, much earlier than previously believed.

On the other hand, a second insight that follows from the analysis of this chapter is that the transition to general incorporation did not always represent a discrete change in the degree to which entrepreneurs enjoyed access to the corporate form. Rather than moving from limited access to truly open access, early general acts often represented more of an intermediate step. Many imposed restrictive terms such as limits on capitalization, or limits on the industries that could be pursued, which forced entrepreneurs to continue to seek special charters for enterprises that did not conform to those terms. Effectively, these states offered open access only to a somewhat limited set of enterprises, and retained discretion over access to the corporate form for all others. More significantly, some Southern and border states specifically excluded nonwhites from access to their statutes, or gave a state official broad authority to deny access to their statute. These were not yet truly impersonal rules in the sense of Wallis (2011).

Moreover, many states that did not adopt general acts offered liberal access to incorporation. Relative to their populations, several of those states granted charters to extraordinary numbers of businesses. Although a general act would have lowered the cost of incorporating and broadened access to the form at least somewhat, it seems likely that at least in the first half of the nineteenth century, states could offer relatively open access to incorporation through chartering, if they wished. This implies that researchers seeking to analyze the effect of general acts or to use general acts as indications of liberal access to the corporate form must take care to account for the selected nature of the states adopting (or failing to adopt) such laws.

Another insight from the analysis of this chapter is that the terms of general acts varied substantially across states. Although most states' laws included passages borrowed from those of other states, and many terms were copied whole cloth from influential acts such as New York's 1848 statute, 
there was significant variation across different regions, with Southern states generally adopting statutes that were less restrictive in many respects than those of other regions. This difference was not simply due to the fact that Southern states had less experience with corporations - even compared to other states with similarly low numbers of existing corporations, Southern states' laws were less restrictive. One might speculate that this was due in part to the extremely restrictive terms governing access to the laws in Southern states. Given that they could ensure that only the "right" elements of the population could use the laws, they may have felt that detailed restrictions on the enterprises they created were unnecessary.

But in addition to this regional variation, some states adopted laws that were quite idiosyncratic. Especially within the West and Midwest, there was substantial variation across states in the structure and degree of restrictiveness of general acts. Iowa's 1847 law - the most permissive of all statutes examined for this study - imposed almost no restrictions on the businesses it incorporated. In contrast, the statutes of the nearby states of Wisconsin, Illinois, and Missouri were substantially more restrictive, with Wisconsin even briefly imposing a rule of one vote per shareholder and unlimited liability. Whereas New England seems to have had its own legal culture and fairly uniform corporation statutes, and the same was true to a somewhat lesser extent of the mid-Atlantic states, there was considerably more variation among the states of the Midwest.

Finally, this chapter has focused on the political significance of the transition to general incorporation. Yet these acts may also have had important economic impacts, and the variation across states in the timing and content of general statutes suggest some fascinating questions that could be pursued in future research. For example, by lowering the cost of gaining access to the corporate form, general acts may have facilitated the formation of smaller corporations that could not have existed in their absence. This would have increased the number of manufacturing enterprises, and may also have changed the size distribution of manufacturing firms. In addition, some states' general acts were quite prescriptive, and included terms that strictly regulated the governance institutions of the businesses they created. The effect of these terms on the rate at which the statutes were utilized is another important question, with relevance to modern policy debates about the wisdom of imposing regulations on the governance institutions of public companies.

\section{References}

Berle, Adolf, and Gardiner Means. 1933. The Modern Corporation and Private Property. New York: Macmillan. 
Bodenhorn, Howard. 2008. "Free Banking and Bank Entry in Nineteenth-Century New York." Financial History Review 15 (2): 175-201.

Brooks, Richard, and Timothy Guinnane. 2014. "The Right to Associate and the Rights of Associations: Civil-Society Organizations in Prussia, 1794-1908." Working Paper, Columbia University and Yale University.

Butler, Henry N. 1985. "Nineteenth-Century Jurisdictional Competition in the Granting of Corporate Privileges.” Journal of Legal Studies 14 (1): 129-66.

Demsetz, Harold. 1967. "Toward a Theory of Property Rights.” American Economic Review 57:347-59.

Dubin, Michael J. 2007. Party Affiliations in the State Legislatures: A Year by Year Summary, 1796-2006. Jefferson, NC: McFarland \& Co.

Dunlavy, Colleen A. 2004. "From Citizens to Plutocrats: Nineteenth-Century Shareholder Voting Rights and Theories of the Corporation." In Constructing Corporate America: History, Politics, Culture, edited by Kenneth Lipartito and David B. Sicilia. New York: Oxford University Press.

Engerman, Stanley L., and Kenneth L. Sokoloff. 2002. "Factor Endowments, Inequality, and Paths of Development among New World Economies." NBER Working Paper no. 9259, Cambridge, MA.

Grandy, Christopher. 1989. "New Jersey Corporate Chartermongering, 1875-1929." Journal of Economic History 49 (3): 677-92.

Guinnane, Timothy, Ron Harris, Naomi Lamoreaux, and Jean-Laurent Rosenthal. 2007. "Putting the Corporation in Its Place." Enterprise \& Society 8 (3): 687-729.

Hamill, Susan Pace. 1999. "From Special Privilege to General Utility: A Continuation of Willard Hurst's Study of Corporations." American University Law Review 49:81-177.

Hansmann, Henry, and Mariana Pargendler. 2010. "Voting Restrictions in 19th Century Corporations: Investor Protection or Consumer Protection?” Working Paper, Yale Law School, Yale University.

Henderson, Gerard C. 1918. The Position of Foreign Corporations in American Constitutional Law. Cambridge, MA: Harvard University Press.

Hilt, Eric. 2008. "When Did Ownership Separate from Control? Corporate Governance in the Early Nineteenth Century." Journal of Economic History 68 (3): 645-85.

_. 2013. "Shareholder Voting Rights in Early American Corporations." Business History 55 (4): 620-35.

Horack, Frank E. 1904. "Some Phases of Corporate Regulation in the Territory." Iowa Journal of History and Politics II (3): 381-93.

Horwitz, Morton. 1977. The Transformation of American Law, 1780-1860. Cambridge, MA: Harvard University Press.

Howard, Stanley E. 1938. "Stockholders' Liability under the New York Act of March 22, 1811." Journal of Political Economy 46 (4): 499-514.

Hurst, James W. 1970. The Legitimacy of the Business Corporation in the Law of the United States, 1780-1970. Charlottesville: University of Virginia Press.

Irwin, Douglas A., and Joseph H. Davis. 2003. "Trade Disruptions and America's Early Industrialization.” NBER Working Paper no. 9944, Cambridge, MA.

Kessler, William C. 1940. "A Statistical Study of the New York General Incorporation Act of 1811." Journal of Political Economy 48:877-82.

McCormick, Virginia E., and Robert W. McCormick. 1998. New Englanders on the Ohio Frontier: Migration and Settlement of Worthington Ohio. Kent, OH: Kent State University Press.

Millon, David. 1990. "Theories of the Corporation." Duke Law Journal 1990:201-62. 
Mulligan, Casey, and Andrei Shleifer. 2005. "The Extent of the Market and the Supply of Regulation." Quarterly Journal of Economics 120 (4): 1445-73.

North, Douglass, John Wallis, and Barry Weingast. 2009. Violence and Social Orders: A Conceptual Framework for Interpreting Recorded Human History. New York: Cambridge University Press.

Romano, Roberta. 1985. "Law as a Product: Some Pieces of the Incorporation Puzzle." Journal of Law, Economics and Organization 1 (2): 225-83.

Seligman, Joel. 1976. "A Brief History of Delaware's General Incorporation Law of 1899.” Delaware Journal of Corporate Law 1 (2): 249-87.

Sylla, Richard, and Robert E. Wright. 2013. "Corporation Formation in the Antebellum United States in Comparative Context." Business History 55 (4): 653-69.

Wallis, John. 2005. "Constitutions, Corporations and Corruption: American States and Constitutional Change, 1842-1852." Journal of Economic History 65 (1): 211-56.

2006. "The Concept of Systematic Corruption in American History." In Corruption and Reform: Lessons from America's Economic History, edited by Edward Glaeser and Claudia Goldin. Chicago: University of Chicago Press.

.2011. "Institutions, Organizations, Impersonality, and Interests: The Dynamics of Institutions.” Journal of Economic Behavior and Organization 79:48-64. 